\title{
Education and Therapy Through Art in the Reality of a Post-Pandemic School
}

\author{
Edukacia i terapia przez sztukę \\ w rzeczywistości szkoły post-pandemicznej
}

\begin{abstract}
The aim of the study presented in the article was to demonstrate the benefits of education and art therapy for students returning to traditional learning after the period of online education caused by the COVID-19 pandemic. The article presents selected Polish and foreign studies on the relationship between the use of information and communication technologies (ICT) and psychological deterioration in schoolage children. Taking into account the probable intensification of such cases related to the widespread use of ICT in teaching during the pandemic, the need for systematic psychological support of the majority of students in the reality of the "post-pandemic school" is observed. Hence, the suggestion to introduce elements of art therapy in Polish schools. Art therapy as an activity facilitating group integration, expression of emotions and self-regulation using art and creative expression was presented as a possibility of adapting educational activities to the new challenges and needs of students. The reflections of Herbert Read, which serve as the conceptual framework for the article, indicate the interpretation of his ideas as a prototype of modern, visionary education incorporating elements akin to the purposes of art therapy.
\end{abstract}

KEYWORDS

post-pandemic school, art therapy, mental regulation of children, multisensory experiences

SLOWA KLUCZOWE szkoła po pandemii, arteterapia, regulacja umysłowa dzieci, doświadczenia multisensoryczne

SPI Vol. 24, 2021/4

ISSN 2450-5358 e-ISSN 2450-5366 DOI: 10.12775/SPI.2021.4.010

Submitted: 1.07.2021 Accepted: 10.12.2021

Miscellanea 


\section{ABSTRAKT}

Celem badania omówionego w artykule było wykazanie korzyści płynq̨cych z edukacji i terapii przez sztukę prowadzonej dla uczniów powracających do kształcenia stacjonarnego po okresie edukacji online spowodowanej pandemiq COVID-19. W artykule przedstawiono wybrane badania polskie i zagraniczne dotyczqce zwiqzku między korzystaniem z technologii informacyjno-komunikacyjnych (ICT) a pogorszeniem się kondycji psychicznej dzieci w wieku szkolnym. Biorq̨ pod uwagę prawdopodobnq mnogość takich przypadków będq̨cych następstwem powszechnego wykorzystywania technologii ICT w nauczaniu w czasie pandemii, zauważa się potrzebę systematycznego wsparcia psychologicznego większości uczniów w realiach „szkoły postpandemicznej". Stąd postuluje się wprowadzenie do polskich szkół elementów arteterapii. Arteterapia jako działanie ułatwiajqce integrację z grupq, wyrażanie emocji i samoregulację, które wykorzystuje sztukę i ekspresię twórczq została przedstawiona jako szansa dostosowania zajęć edukacyjnych do nowych wyzwań i potrzeb uczniów. Refleksje Herberta Reada stanowiq koncepcyinq ramę artykułu, ponieważ autor ten postrzega interpretację swoich idei jako prototyp nowoczesnej, wizjonerskiej edukacji, zawierajqcej elementy pokrewne celom arteterapii.

\section{Introduction}

The aim of this text is to indicate the positive impact of art therapy in the areas of students' lives that may be most affected by the negative factors of online learning caused by the COVID-19 pandemic. The concern for the harmful consequences of information and communication technologies (ICT) on the emotional and intellectual well-being of children is not a new research issue (Spitzer 2012, 2016; Garnder, Davies 2013); however, the prevalence of online learning caused by the current pandemic changes the scale of the described phenomena. For this reason, this topic requires a different perspective and formulation of more detailed research problems which are directly related to the difficulties children may face in a post-pandemic school. Thus, self-regulation, self-expression, group relationships, and sensory stimulation as those aspects of art therapy that might prove to be most therapeutic for students in this particular period of educational transformation constitute the main focus of these considerations. The article is based on literature studies 
(analysis of existing documents), which enable the study and description of social phenomena (Euczewski, Bednarz-Euczewska 2012).

In his inaugural lecture on The Place of Art in a University given in 1931, Herbert Read, a well-renown art historian and education theorist, agreed with another great mind of the bygone era-John Ruskin, postulating that the emphasis on the intellectual dimension of education has to be balanced out by activities developing aesthetic sensitivity (Read 1931). Thus, almost a century ago, there were thinkers who already noticed and articulated the danger of one-sided and over-intellectualized educational instruction, especially prominent in the times of rapid technologization in the beginning of the $20^{\text {th }}$ century. Such conditions have become even more prevalent in the $21^{\text {st }}$ century, and especially noticeable in the sudden change of the modus operandi of education in the times of the COVID-19 pandemic.

The pandemic seems to impose unprecedented changes on almost every aspect of social life with education being no exception. Schooling in Poland transitioned from traditional to online almost overnight on the $25^{\text {th }}$ of March 2020. This rapid change combined with social isolation resulted in a widespread modification of the ways in which all students in the country (and in many other parts of the world as well) learn and function socially. Excessive screen time and children's daily use of information and communication technologies (ICT) became unavoidable and were shortly after proclaimed as the "new normal." Understandably enough, in the onset of this crisis, the main focus was on providing all children with adequate devices for online learning and preventing them from educational exclusion. However, as this state of affairs continued, new concerns about exposure to screens emerged and have not been resolved yet. The aforementioned considerations of Read seems to be more pertinent than ever. The reality in which technologized mode of education mostly supports operational thinking and the development of reasoning while limiting activities involving group art making, sensory experience of different materials, aesthetic sensitivity and emotional regulation might create the need for some measures to be taken once the students find themselves back in the classrooms. The introduction of the elements of art therapy in grades 1-3 within Polish public schooling should be thoroughly considered as a potential way of counteracting the negative side effects of online education. 


\section{The doubts and risks of online learning}

Although there are multiple reports of the benefits of ICT in the realm of social interactions and cognitive development of children, they are usually balanced with some warnings and more caution on the possible dangers including to the physical and mental wellbeing of pupils. There are also studies which already demonstrate an extremely critical approach to the topic, like Manfred Spitzer's Dementia Digital (2012), where the author focuses on the detrimental consequences of the digital media on the cognitive and emotional functions. His emphasis is laid on the negative cognitive repercussions, such as problems with information processing among children and teenagers. Similar arguments reverberate not only in the relevant body of Nicholas Carr's research but it is also signaled in its very title The Shallows: What the Internet Is Doing to Our Brains (2013). Carr criticizes the changes encouraged with the popularity of the Internet, predominantly the permanent distraction accompanying thought processes. It is worth noting here that some of the preliminary research on education in the times of Covid-19 pandemic cautiously expresses similar concerns. In his text Neurobiologiczny kontekst edukacji zdalnej [Neurobiological context of online learning], Marek Kaczmarczyk notes that prolonged exposition to the blue light of screens poses a threat of physical overstrain and stress response (Kaczmarczyk 2020: 24). He advises introducing as many non-screen activities as possible in between online meetings in order to partly relieve the technological load.

Other available studies examine students of various age groups also in more nuanced fashion, for example the publication Mate $d z i e-$ ci w świecie technologii informacyjno-komunikacyjnych [Young children in the world of ICT] scrutinizes the available data considering kindergarten children (Pyżalski 2017b). After listing the benefits of ICT (Klichowski et al.2017), the author also discusses some threats of these technologies. Pyżalski classified the main areas of possible risk as follows: health (posture defects, eyesight defects, and obesity), the cognitive sphere (adopting dysfunctional patterns of behavior, e.g. when playing inappropriate computer games), conscious decision-making (exposure to a wide range of advertisements; product placement), cyberbullying (receiving or sending aggressive messages), 
sexuality (exposure to or involvement in pornography) (Pyżalski 2017a). The author differentiates the level of danger depending on the fact whether or not a child has (unlimited) access to the Internet. When a child does use the Internet during their screen time, the risk of negative effects automatically rises especially when the activity is not supervised or limited by a parent or a caretaker. Such an undesirable impact of the Internet on the social relationships among older children is the subject of another study by Pyżalski (2012) who devotes his whole publication to cyberbullying and other forms of online aggression of teenagers.

The publication Mate dzieci w swiecie technologii informacyjno-komunikacyjnych [Young children in the world of information and communication technologies] (2017b) provides yet another perspective on the Polish digital landscape of the youngest users. The study not only lists the advantages and disadvantages of ICT among children at the ages between three and six, but also reflects on the contextual modifications of Internet use in recent years. Dominik Batorski notes that ICT constitutes the most natural element of preschool children's environment. Moreover, he emphasizes the rapid lowering of the age when children start to use the Internet. The percentage of three-year-olds using the Internet doubled in Poland in two years, reaching 21\% in 2015 (Batorski 2017: 79).

However, the most alarming findings on the negative effects on the mental condition of adolescents were noted by Jean M. Twenge et al. (2017). The researchers observed a disturbing rise in depressive symptoms, suicidal thoughts, and suicide rates among American teenagers aged between 13 and 18 and their prolonged time spent on new media from 2010 to 2015 . The study correlates the rise in mental problems with the popularity of smartphones and, consequently, the longer daily screen time. Between 2012 and 2015, the number of smartphone owners almost doubled in the U.S. Concurrently, the suicide rate rose by $31 \%$ and severe depressive symptoms by $33 \%$ among adolescents from 2010 to 2015. The findings were even more alarming once they were subcategorized according to sex with females demonstrating more extreme tendencies: suicide rates increased by $65 \%$ and severe depression symptoms rose by $58 \%$ among teenage girls. Interestingly, Twenge et al. (2017) suggest that the possible link between the deterioration of teenagers' mental wellbeing and their 
usage of new media depends on the time of screen exposure. Among the teenagers who devoted less than an hour of their day to electronic devices, $28 \%$ more demonstrated suicide-related behaviour. This risk rose by $48 \%$ when the adolescent users of ICT spent more than five hours a day on those activities.

The data collected by researchers implies that an under-aged user of electronic devices should be somehow equipped with the strategies and tools protecting them from the adverse repercussions of the new media use. The simplest solution seems to be limiting screen exposure. However, this was already difficult before the pandemic and at a time when online education was mandated by the state from early 2020, regular daily use of electronic devices has proven to be unavoidable: virtually every schoolchild had to spent more than the alarming five hours online. Furthermore, if we want teenagers to be prepared to counteract the negative consequences of (especially unavoidable and urgent) introduction of online learning, they should already be taught some strategies to have the competences and tools ready at their disposal. Thus, taking into consideration the subtle and individual nature of developing such competences, systematic measures should be taken long before adolescence to support and gradually develop the capabilities which may be essential to mental health in the critical age of puberty. Moreover, the survey of Payton Q. Fors and Deanna M. Barch (2019) implies that mental problems resulting from electronic media use (EMU) affect younger teenagers and children. The researchers surveyed 4139 children aged 8.9-11 years and their parents. Thus, children even younger than those researched by Twenge et al. (2017) might need not only some preparation for future challenges but also some protection against the negative outcomes of EMU they may be already experiencing. This is especially relevant when bearing in mind Fors and Barch's (2019) findings which suggest that even if EMU is not the sole reason of depression, it might enhance its harmful effects:

Our findings are consistent with the body of literature linking EMU to depression in both children and adolescent .... This relationship could suggest that children with depression are using EMU to cope with negative feelings. Alternatively (or in addition), a child's depression could interfere with them engaging in non-EMU activities, particularly on the weekends, with EMU potentially becoming a default activity used to occupy their time. This explanation would be in line with the concept of 
experiential avoidance .... These hypotheses suggest the possibility that modification of EMU might be a useful part of interventions designed to target child depression. EMU interventions, such as limiting time spent on electronics and encouragement of prosocial activities, might be effectively targeted for children at risk for depression, though it is less clear whether this would be as effective for anxiety. However, more evidence about the causal relationship between EMU and depression or anxiety is needed; if EMU is an outcome rather than a contributor to depression or anxiety, modifying EMU may have limited positive impact (Fors, Barch 2019: 914).

The interesting points raised by Fors and Barch (2019) suggest that a child prone to depression might interpret online classes as an invitation to use new media as an escape from difficult experiences even once the actual learning has finished. For instance, MS Teams, a platform frequently adopted in Poland for online learning during the COVID-19 pandemic enables students to chat, exchange pictures, etc. after the class, paving the way for other electronic media use (such as those mentioned by Fors and Barch like video gaming, video chatting, using tablets and television screens). The link between online schooling and other activities involving screen time seems even more plausible when the social context of the recent pandemic is considered. A lot of parents could not supervise their children's usage of electronic devices because they had to work either in an office or remotely. Admittedly, more than ever before, many groups involved in the educational process could experience themselves that education is in fact a social phenomenon. Thus, the period of online education caused by the pandemic was yet another practical realization of the theory formulated by a renown Polish sociologist, Florian Znaniecki (1998), according to whom education occurs in a close relationship with its sociocultural background. In their book Dysfunkcjonalność spoteczeństwa wychowujacego [Dysfunctionality of the educating society], Maria Dąbrowska-Bąk and Katarzyna Pawełek refer to Znaniecki's theories while analyzing the dysfunctionality of the chosen local educational institutions:

As for social conditions, it is the basic educational environment (parents, neighbors, peers and the school) that play a special role in the educational processes, as well as institutions that either support education or intervene when the socialization process begins to sway. If society wants to mold young people to become its members, it must utilize the 
above-mentioned components of the educational environment more or less effectively, by laying down clear and precise requirements. Otherwise, an immature person who is at the center of educational activities will not receive clear and precise guidelines about what is and what is not appropriate behavior. This would lead to society not being able to perform its function and result in young people "socializing themselves" on their own (Dąbrowska-Bąk, Pawełek 2013: 187).

Since a pandemic is by definition a time of crisis, it triggered some challenging conditions of educational processes where other than institutional components became to play a more important role than before. The immediate communities of a student like the closest family and neighbors were also under the mental and physical constraints posed by COVID-19 pandemic. Therefore, it is plausible that at least some of the social factors of educational processes, like the home setting, were unfavorable, especially in dysfunctional families where children had to spend more time because they did not attend traditional classes. In line with Dąbrowska-Bąk and Pawełek's argument, those children may have encountered a lack of any limitations or regulations of their use of electronic devices. Likewise, institutional intervention was also limited as it was more difficult to detect some deviations in the socialization process like cyberbullying, isolation, and avoidant or additive use of ICT when they took place within the virtual space.

Nevertheless, online education, and the consequent increase in time spent in front of the screen, was understood as a necessity in the face of ever prolonging social isolation. For all of those reasons, as already indicated above, the modification of EMU turned out to be especially difficult in that time.

\section{Areas of damage and prospects for redress}

Now, when the potential damage has already been done, we should focus on counteracting the negative consequences of online education. Nonetheless, the actions that will be undertaken could mitigate overexposure to screen devices as well as provide some preventive strategies for the future in case online learning returns. What is more, taking into consideration the already mentioned findings of Twenge et al. (2017), which are based on data before the pandemic 
and widespread online learning, self-regulating competences seem to be advantageous for a majority of students who live in a world of ubiquitous electronic devices. Self-regulation is understood here in a narrow sense relating to the ability to look for healthier ways of balancing discomfort than additive or avoidant use of ICT.

However, if we are to design some strategies devoted primarily to compensating for the damage done by almost a year of online education, there are also other areas besides the responsible, regulated pattern of EMU which demand our special attention. One of them is the social bonds in a peer group within the natural context of a school setting, where these relationships may be created through various kinds of activities, experiences and pursuits. While platforms like MS Teams allow exchanging messages and video chatting, such kind of communication excludes the development of friendships in a more fluid, intuitive and non-verbal setting. Moreover, not only friendships but also normal functioning within a bigger group than the student's family is suspended. Along with the deficiency of social competences, emotional shortages, such as a feeling of loneliness and isolation, might emerge.

Similarly to relationships which require active, real-live circumstances to evolve, education also thrives in such a setting. Although there are many studies which document how ICT facilitates education (Klichowski et al.2017), the overlooked aspect of online learning is the lack of sensory stimulation. The electronic devices employed in education during the pandemic precluded multisensory contact with various materials, especially natural ones, and the possibility of their transformation in a symbolical, meaningful way. Thus, the whole educational process became devoid of a very important, multisensory aspect which resulted in a very unilateral educational approach. This recalls the already mentioned concerns of Read about over-intellectualized school curricula which do not develop aesthetic sensitivity in the urbanized and technologized reality of the first half of the $20^{\text {th }}$ century. Over eighty years later, similar concerns still reverberate in some publications. In her book Arteterapie dla dzieci i mtodzieży [Art therapy for children and adolescents], Monica Blotevogel (2013) notes that the omnipresence of media overload creates supernormal stimuli which might disturb a child's symbolic and conceptual mental systems. Referring to her therapeutic experience, Blotevogel 
concludes that psychosocial pressure and low quality of life combined with a lack of experience in using one's own senses and creative expression result in a disturbed development of children's innate coping mechanisms (Blotevogel 2013: 118). In such a situation, a child is unable to adopt a healthy mechanism in the critical circumstances which challenge their well-being. These observations are disturbingly reminiscent of the conditions in which some of the students had to function during online learning.

Although the various negative repercussions of schooling during the COVID-19 pandemic are of a different kind, the introduction of the elements of art therapy to the post-pandemic school could possibly alleviate all of them. However idealistic such hopes might seem, art therapy has the potential to positively affect students on many levels; therefore it should be at least taken into consideration when the post-pandemic educational reality is to be improved.

\section{Self-regulation and self-expression}

One of the many advantages of art therapy is its usefulness in helping those experiencing problems with setting boundaries for themselves. This issue is tackled by Tomasz Rudowski (2013) in Edukacja i terapia przez sztuke [Education and therapy through art] where he claims that art therapeutic activities promote self-regulating skills which facilitate social functioning. Through repeated artistic expression, self-esteem improves and that serves as a regulating factor for increased social adjustment. Moreover, Rudowski observes that this, often difficult, process frequently trains the ability to vary gratification in order to comply with the expectations of others (Rudowski 2013: 34). Here, self-regulation is closely related to self-expression, as according to Rudowski, art therapy stimulates the ability to minimize one's own discomfort through the means of artistic expression (Rudowski 2013:34). Nevertheless, this treatment of one's own distress has nothing to do with experiential avoidance as described by Fors and Barch (2019): "Anxiety and depression have repeatedly been linked to people's levels of experiential avoidance, defined as the effort to suppress unwanted emotions and experiences, while not changing the emotions and experiences themselves" (Fors, Barch 2019: 908). Rudowski emphasizes that therapeutic expression 
through art, on the contrary, aims to unravel and explore the social and psychological deficits which were previously unrecognizable although the discomfort they produced could have been acutely felt. In fact, externalization of mental experiences, release of accumulated tensions and restoring mental balance are some of the functions of expression listed by Grażyna Szafraniec in the article in which she explores the boundary between art and therapy (Szafraniec 2003: 111). Thus, artistic expression is not an evasive activity, but serves the purpose of transformation through confrontation with one's feelings. Satisfaction derived from such transformational acts influences mental wellbeing, as noted by Stanisław Popek (2010: 433).

It is worth pointing out that artistic expression operates with different codes than verbal expression. Hence, younger children who may lack lexical resources have a possibility to communicate their experience in a way which enables them to convey their feelings and even construct new meanings which are unattainable within the space of verbal communication.

\section{Group relationships}

The traditional classroom setting comprises a group of children and a teacher who, generally speaking, plays the role of a supervising adult. This unique arrangement could serve as a conducive environment for some art therapy activities aiming at creating a bond between all parties in a safe atmosphere. The distinguished visionary, Read realized that a good teacher-student relationship is a prerequisite for successful art education and education in general. His description of the desired educational setting seems to be identical to that used in art therapy:

For whatever aspect of education we take, and at whatever stage, the rapport established between the teacher and the child is all-important factor. The growth of confidence, the elimination of fear, the binding force of love and tenderness - these are the elements with which the teacher must work. Not only the assimilation of knowledge, the acceptance of discipline, and the realization of self-depend on the right development of these psychological processes, but what is even more important, the integration of the individual of the group or society to which he belongs (Read 1944: 235). 
These words appear to be even more relevant nowadays when the social bonds have become affected by long isolation. Read links the accepting, caring and safe atmosphere of educational space with the social integration which should take place within that space. A similar link is noted by Emma Mills and Stephanie Kellington (2012) in their analysis of the effectiveness of group art therapy offered to children who have witnessed domestic violence. Mills and Kellington argue that art therapy in a group setting alleviates the shame and silencing which accompany the experience of domestic violence. However, their article also provides a brief overview of literature which accentuates the general benefits of group art therapy for latency-aged children (Mills, Kellington 2012: 4). The authors emphasize that the safe environment of group art therapy allows processing the trauma related to children's experiences. ${ }^{1}$ In Poland, Ewelina J. Konieczna also advocates the group form of art therapy provided to children of similar age and perceptual possibilities. Among the factors that decide about the selection of participants, Konieczna mentions similar age, problems, forms of therapeutic influence and a shared space (Konieczna 2007: 15). Although a school class consists of many individuals who already own their distinctive life stories, it also meets the main demands of the art therapy group enumerated by Konieczna. In other words, the reality of a post-pandemic class unites a group of similar-aged pupils through the comparable experience of social isolation during online learning and, for the substantial part of the day, situates them in the space of the same school and even classroom. With proper caution and expertise, some art therapy elements might be introduced to

1 Interestingly enough Mills and Kellington (2012) raise a similar argument to the one articulated in the article of Fors and Barch (2019) concerning the reason of the deteriorating mental wellbeing of children. Mills and Kellington realize that "it is important to underline here that the potential negative outcomes associated with the experience of witnessing DV are not an unavoidable product of the traumatic experience itself, but rather result when the trauma has not been adequately processed" (Mills, Kellington 2012: 3). A similar argument reverberates in the already quoted fragment by Fors and Barch where they suggest that it is not a particular disturbing emotion which causes depression among children but rather suppression and avoidance of confrontation with it. Thus, group art therapy seems to provide the space for such confrontation instead of using other activities characteristic for experiential avoidance such as additive EMU. 
address the emerging issues relating the social interaction and group dynamics after the time of pandemic-induced isolation. Though group art therapy poses an exceptional challenge, Diane Weller suggests that it is uniquely beneficial in that it provides not only the understanding of one's own behavior but also of the broad sociocultural context of collective patterns of behavior in the complex reality of our contemporary world (Weller 2012: 425). Surely, the unexpected pandemic and the consequences it brought must have confused most children and the art therapy activities performed in the classroom could offer a possibility for better identification and understanding of the sudden collective changes which have taken place.

Likewise, Read's ideas on the purpose of artistic education echo Znaniecki's reflections on education which does not adapt to sudden social change (Znaniecki 1998: 65). In Education Through Art, Read concludes that education "must be pursued simultaneously in the developing, adapting individual, and in the ever-changing community culture and tradition" (Read 144: 325). Some elements of group art therapy introduced into post-pandemic schools might be an active response to social changes aiming at synchronic adaption of the educational setting to the real needs of children. In such a modified setting, a child is indeed treated as a participant and co-creator of society and is entitled to receive some guidance and support when their social relationships and existence are at stake in the times of crisis.

\section{Sensory stimulation}

The last area of potential art therapeutic intervention discussed here is the possibility of multisensory experience. As already signaled, one of the undisputed drawbacks of online learning is the unification of educational tools which do not promote sensory, non-verbal development. Paradoxically, within the plethora of online platforms, it is inherently impossible to enjoy the benefits of diverse sensory stimuli. Although various creative endeavors are, of course, possible in the digital space and online learning, Jacek Ścibor rightly notices that children are far more often passive recipients of Internet content than its creators (Ścibor 2020: 59). However, even if they are encouraged to express themselves artistically in the digital medium, 
digital tools, due to their intrinsic limitations, do not offer sensual richness of natural materials with their attributes like texture, smell, and sometimes even sounds(!). In contrast, many art therapy scenarios revolve specifically around the senses and the physical experience of one's existence in the world. One of such instances is Wiesław Karolak's compilation of art therapy scenarios for children and teenagers where he centers each activity on a given sense, season of the year or physical sensation (Karolak 2019).

Contact with natural materials or artistic activities involving various tools and varied cognitive operations seems more suitable for processing and communicating the multifaceted experience of our existence. In Arteterapia i warsztaty edukacji twórczej [Art therapy and creative education workshops], Maja Stańko-Kaczmarek comments on this aspect of art therapy, realizing that the mode of communication specific to artistic expression is more suitable to reflect on strong positive and negative emotions (Stańko-Kaczmarek 2013: 84). Multisensory artistic activity is also more related to experiences taking place within the realm of our senses (Stańko-Kaczmarek presents examples of tactile sensations like gusts of wind, sunbeams on the face, or pain) and provides a chance to effectively share them with others outside the sphere of verbal communication. Stańko-Kaczmarek states that once the initial hindrances of a new mode of expression are overcome, a child could express oneself more fully than before. This is also possible because uninhibited artistic expression simultaneously improves communication with oneself and others (Stańko-Kaczmarek 2013: 83). The observations of Mills and Kellington are noteworthy here as well. The authors emphasize that "in an art therapy group, in particular, the art-making can be used to create a shared 'visual language' among the group members and thus expand the opportunities available for connection and meaning-making" (Mills, Kellington 2016: 6).

Another crucial factor of multisensory experience relates directly to learning processes and cognitive abilities. In her discussion of this topic, Blotevogel (2013: 119) refers to the works of Noah Hass-Cohen and Richard Carr (2008) who noticed that artistic endeavors in the visual arts seem to stimulate the release of the neurotransmitter acetylcholine. The ultimate result of this secretion is emotional regulation and also improved long-term memory and cognitive changes 
that facilitate coping with problematic situation. This is highly desirable because acetylcholine is responsible for visual processes and memory.

Several neurological studies provide more arguments for using art therapy especially for children with trauma and post-traumatic stress disorder (PTSD). While it would be far-fetched to say that online learning during the pandemic triggered PTSD in the majority of pupils, it certainly may have exacerbated exposure to domestic violence in those children who were already living in dysfunctional families before the pandemic. Therefore, art therapy intervention should also be considered for this reason. Mills and Kellington (2016) argue that art therapy helps children from such families when verbal communication does not perform a therapeutic function. The authors briefly explain the neurological mechanism of this process:

Art therapy also brings unique benefits in allowing procedural memory to be activated in the safe, contained way that is vital for psychodynamic work. Accessing procedural memory is key to the treatment of trauma (Green 2003) as these types of memories are often located in the amygdala where responses to traumatic or 'emergency' situations like flight, fright, fight or freeze are also determined. For traumatic incidents to be processed, the brain must be able to take the experiences from the amygdala and process them, calmly and reflectively, in the hypothalamus. Post-traumatic stress disorder (PTSD) and other potentially adverse consequences of trauma are the result of trauma staying in the amygdala and flooding it (Mills, Kellington 2016: 3).

\section{Conclusions}

Taking into consideration all the arguments presented here, some elements of art therapy intervention appear to be beneficial in the process of compensating and processing the experience of COVID-19 pandemic itself as well as the online education taking place in that period. The undoubted advantage of art therapy in this situation is its synchronicity understood as the possibility to work on improving social/ group relationships, and self-regulation through self-expression and multisensory experience at the very same time. One might argue that art therapy activities in schools are redundant, especially for younger children who have art classes. However, art 
classes as defined in the Polish core curriculum for grades 1-3 do not have therapeutic objectives. As Wita Szulc accurately observes, artistic activity is not synonymous to the therapeutic effect of art (Szulc 2001: 126). In art therapy, the communicative potential of artistic creation is harnessed because its symbolic language is what determines its therapeutic value. Although, sometimes the fields of art education and art therapy may overlap, art therapy takes place only when the participant feels that every kind of artistic expression is allowed and respected (Blotevogel 2016: 122). Moreover, mastering artistic techniques and visual perception is not the fundamental purpose of art therapy, but falls within the scope of art education (Stańko-Kaczmarek 2013: 29). Thus, the boundary between art therapy and other adjacent disciplines has been already researched and delineated by science (Szulc 2011; Rubin 2010) as well as discussed in a less academic manner (Handford 2009a, 2009b).

Read has been cited and frequently referred to in this article because his understanding of artistic education can be interpreted as more akin to art therapy rather than to art education as we know it from Polish primary schools. That is why Read's reflections provided a certain framework for this discussion. Nevertheless, it is important to remember about the requirements for appropriate art therapy sessions, like qualified therapists with expertise. This prerequisite is signaled by Wita Szulc and Beata Skwarek who clearly state that although some elements of art therapy might be straightforwardly employed in primary schools, a teacher should not be equated with a therapist unless they have obtained the required qualifications (Szulc, Skwarek 2017: 96).

Unquestionably, the preparation of qualified staff along with other formal and administrative challenges accompanying the introduction of art therapy interventions might provoke certain objections. These should be addressed in future research and should not be a reason to dismiss the preventing, compensating and healing benefits of art therapy in the reality of the post-pandemic school. 


\section{Bibliography}

Batorski D. (2017). "Dzieci z sieci - dostęp i korzystanie z internetu przez dzieci w wieku przedszkolnym," in J. Pyżalski (ed.), Mate dzieci w świecie technologii informacyjno-komunikacyjnych, Łódź: Wydawnictwo Eter, pp. 79-94.

Blotevogel M. (2013). “Terapia przez sztuki plastyczne,” in T. Stegemann, M. Hitzeler, M. Blotevogel (eds.), Arteterapie dla dzieci i mtodzieży, Gdańsk: Harmonia Universalis, pp. 107-120.

Carr N. (2010). The Shallows: What the Internet Is Doing to Our Brains, New York-London: W.W. Norton \& Company.

Dąbrowska-Bąk M., Pawełek K. (2013). Dysfunkcjonalność lokalnego spoteczeństwa wychorwujacego, Poznań: Wydawnictwo Naukowe Uniwersytetu Adama Mickiewicza.

Fors P.Q., Barch D.M. (2019). "Differential Relationships of Child Anxiety and Depression to Child Report and Parent Report of Electronic Media Use," Child Psychiatry and Human Development, vol. 50, pp. 907-917, https://doi.org/10.1007/s10578-019-00892-7 [access: 10.05.2021].

Gardner H., Davis K. (2013). The App Generation: How Today's Youth Navigate Their Identity, Intimacy and Imagination in a Digital World, New Haven (CT)-London: Yale University Press.

Green V. (2003). Emotional Development in Psychoanalysis, Attachment Theory and Neuroscience: Creating Connections, New York: Brunner; Routledge.

Handford O. (2009a). Terapia zajęciowa czy arteterapia?, 31.07.2009, https:// olahandford.wordpress.com/2009/07/31/terapia-zajeciowa-czy-arteterapia/ [access: 01.06.2021].

Handford O. (2009b). Arteterminologia, 27.07.2009, https://olahandford. wordpress.com/2009/07/27/arteterminologia/ [access: 1.06.2021].

Hass-Cohen N., Carr R. (2008). Art Therapy and Clinical Neuroscience, London: Jessica Kingsley Publishers.

Kaczmarczyk M. (2020). "Neurobiologiczny kontekst edukacji zdalnej," in J. Pyżalski (ed.), Edukacja w czasach pandemii Covid-19. Z dystansem o tym, co robimy obecnie jako nauczyciele, Warszawa: EduAkcja, pp. 20-25.

Karolak W. (2019). Arteterapia dla dzieci i mtodzieży. Scenariusze zajęć, Łódź: Wydawnictwo Uniwersytetu Łódzkiego.

Klichowski M. et al. (2017). "Jak technologie informacyjno-komunikacyjne mogą wspierać rozwój dziecka w wieku przedszkolnym? Studium teoretyczne," in J. Pyżalski (ed.), Mate dzieci w świecie technologii informacyjno-komunikacyjnych. Pomiędzy utopijnymi szansami a przesadzonymi zagrożeniami, Łódź: Wydawnictwo Eter, pp. 115-157.

Konieczna E.J. (2007). Artetrapia w teorii i praktyce, Kraków: Oficyna Wydawnicza „Impuls”. 
Łuczewski M., Bednarz-Łuczewska P. (2012). "Analiza dokumentów zastanych," in D. Jemielniak (ed.), Badania jakościowe. Metody i narzędzia, vol. 2, Warszawa: Wydawnictwo Naukowe PWN, pp. 163-188.

Mills E., Kellington S. (2012). "Using Group Art Therapy to Address the Shame and Silencing Surrounding Children's Experiences of Witnessing Domestic Violence," International Journal of Art Therapy, vol. 17, no. 1, pp. 3-12, DOI: 10.1080/17454832.2011.639788 [access: 5.04.2021].

Popek S. (2010). Psychologia twórczości plastycznej, Kraków: Oficyna Wydawnicza „Impuls”.

Pyżalski J. (2012). Agresja elektroniczna i cyberbullying jako nowe ryzykowne zachowania mtodzieży, Kraków: Oficyna Wydawnicza „Impuls”.

Pyżalski J. (2017a). "Dzieci w wielu przedszkolnym w świecie technologii informacyjno-komunikacyjnych - w stronę zagrożeń," in J. Pyżalski (ed.), Mate dzieci w świecie technologii informacyjno-komunikacyjnych. Pomiędzy utopijnymi szansami a przesadzonymi zagrożeniami, Łódź: Wydawnictwo Eter, pp. 159-181.

Pyżalski J. (ed.) (2017b) Mate dzieci w świecie technologii informacyjno-komunikacyjnych. Pomiędzy utopijnymi szansami a przesadzonymi zagrożeniami, Łódź: Wydawnictwo Eter.

Read H. (1931). The Place of Art in a University: An Inaugural Lecture Given at the University of Edinburgh on 15 $5^{\text {th }}$ October 1931, London: Oliver and Boyd.

Read H. (1944). Education Through Art, London: Faber and Faber.

Rubin J. (2010). Introduction to Art Therapy, New York: Routledge.

Rudowski T. (2013). Edukacja i terapia przez sztukę. Arteterapia w świetle doznań transakcyjnych, Warszawa: Eneteia.

Spitzer M. (2012). Dementia Digital, Editiones B.

Spitzer M. (2016). Cyberchoroby. Jak cyfrowe życie rujnuje nasze zdrowie, trans. M. Guzowska, Wydawnictwo Dobra Literatura.

Stańko-Kaczmarek M. (2013). Arteterapia i warsztaty, Warszawa: Difin.

Szafraniec G. (2015). "Między sztuka a terapią," in M. Knapik (ed.), Dziecko isztuka. Recepcja-edukacja - wsparcie - terapia, Katowice: Wydawnictwo Uniwersytetu Śląskiego, pp. 103-139.

Szulc W. (2001). Sztuka w stużbie medycyny. Od antyku do postmodernizmu, Poznań: Akademia Medyczna.

Szulc W. (2011). Arteterapia - narodziny idei, erwolucja teorii, rozwój praktyki, Warszawa: Difin.

Szulc W., Skwarek B. (2017). “Arteterapia w pracy pedagogicznej,” Zeszyty Naukowe Pañstwowej Wyższej Szkoty Zawodowej im. Witelona w Legnicy, vol. 22, no 1, pp. 93-107.

Ścibor J. (2020). "Wstrzymaj siebie, rusz ucznia: e-nauczanie a e-twórczość," in J. Pyżalski (ed.), Edukacja w czasach pandemii Covid-19. Z dystansem o tym, co robimy obecnie jako nauczyciele, Warszawa: EduAkcja, pp. 59-63. 
Twenge J.M., Joiner T.E., Rogers M.G., Martin G.N. (2017). "Increases in Depressive Symptoms, Suicide-Related Outcomes, and Suicide Rates Among U.S. Adolescents After 2010 and Links to Increased New Media Screen Time," Clinical Psychological Science, vol. 6, no. 1, pp. 3-17, DOI: $10.1177 / 2167702617723376$ [access: 26.05.2021].

Weller D. (2012). "Artetrapia grupowa," in C.A. Malchiodi (red.), Arteterapia. Podręcznik, trans. E. Bochenek, Gdańsk: Harmonia Universalis, pp. 410-426.

Znaniecki F. (1998). Education and Social Change, edited by E. Hałas, Frankfurt am Main: Peter Lang.

\section{ADDRESS FOR CORRESPONDENCE}

\section{Eliza Kaja Gładkowska}

University of Warmia and Mazury in Olsztyn

Faculty of Social Sciences

e-mail: eliza.gladkowska@uwm.edu.pl 